\author{
체지방 감소 다클론 후보 항체가 비거세돈의 체중, 분 소화율 및 혈액 \\ 대사물질에 미치는 영향 \\ 최창원 ${ }^{1}$ 백경훈 $^{2} *$ 조성백 $^{3} \quad$ 오영균 $^{3}$ 홍성구 $^{3} \quad$ 최창본 $^{2}$ \\ ${ }^{1}$ 대구대학고, ${ }^{2}$ 영남대학교, ${ }^{3}$ 농촌진흥청 국립축산과학원
}

\title{
Effects of Polyclonal Antibody Candidate to Adipocytes for Reducing Body Fat on Body Weight, Fecal Digestibility and Blood Metabolites in Pigs
}

Chang Weon Choi ${ }^{1}$, Kyung Hoon Baek ${ }^{2 *}$, Sung Back $\mathrm{Cho}^{3}$, Young Kyoon $\mathrm{Oh}^{3}$, Seong Koo Hong ${ }^{3}$ and Chang Bon $\mathrm{Choi}^{2}$

${ }^{1}$ Daegu University, ${ }^{2}$ Yeungnam University, ${ }^{3}$ National Institute of Animal Science, RDA

\begin{abstract}
Twelve pigs were used to investigate the effects of polyclonal antibody candidate against abdominal (AAb) and subcutaneous adipocyte membrane proteins $(\mathrm{SAb})$ on body weight, fecaldigestibility and blood metabolites. When AAb and SAb developed by Choi et al. (2010) were injected to pigs, the numerical increase in BW (body weight) occurred at 4 weeks post-treatment, but BW for an entire period was also increased, indicating that the BW increase may not be affected by the antibodies injection. Antibodies treatment did not affect $(\mathrm{P}>0.05)$ fecal digestibility of dry matter, crude protein, crude fat and crude fiber. Fecal digestibility of crude ash for control (no treatment) at 2 weeks decreased, and that for non-immunized serum treatmentgroup at 4 weeks post-treatment increased, respectively $(\mathrm{P}<0.05)$. However, fecal digestibility of crude ash for AAb and SAb groups did not significantly change. At 4 weeks after the antibodies treatment, blood urea $\mathrm{N}$ concentration for AAb and SAb groups was significantly increased $(\mathrm{P}<0.05)$. However, these increases may not be caused by the antibodies treatment because similar pattern in blood urea $\mathrm{N}$ concentration occurred before the antibodies treatment. Antibodies treatment did not affect concentration of plasma glucose and triglycerides $(\mathrm{P}<0.05)$. Compared with control, concentration of plasma total cholesterol for AAb and SAb groups at 4 weeks post-treatment was significantly $(\mathrm{P}<0.05)$ decreased. This may suggest that body fat reduction possibly occurs. In conclusion, the AAb and the SAb developed by Choi et al. (2010) may have safety in nutritional physiological metabolism in pigs. Further study on in vivo fat reduction of the antibodies against abdominal and subcutaneous adipocytes of pigs should be required for fat-reduced pork production.
\end{abstract}

(Key words : Pig, Polyclonal antibody, Fecal digestibility, Blood metabolites, Fat)

서 론

육류소비 시 필수적으로 동반되는 지방 섭취를 줄이기 위한 연구 는 육류섭취로 인한 대사성 질환의 발병도가 비교적 높은 서구권에 서 시작되었고(Flint 등, 1986; Kestin 등, 1993; Moloney, 1995), 우리나라의 경우 가축의 불가식 지방 감소 연구는 물론 향 후 인간비만증의 치료기법으로써의 확대 등이 기대되면서 돼지 (Choi와 Lee, 1996; Choi 등, 1998 2010), 한우(Choi 등, 1997; 2008), 흰쥐 (Baek과 Choi, 2002) 등 다양한 동물에서 시도되었 다. 특히, 돼지의 경우 육류 자체의 고지방뿐만 아니라, 다른 축종 에 비해 인간과의 생리적 유사성으로 인해 항체의 생산 및 항체가 가지는 지방세포 독성효과 등 관심의 대상이 된 것도 사실이다
(Kestin 등, 1993; Moloney 등, 1994). 한편, Choi 등 (2010)은 돼지의 주요 장기 (심장, 신장, 간장, 비장, 폐 등)에 영향을 주지 않으면서도 지방 부위별로 선택적으로 감소 가능한 다클론 후보항 체 결과를 발표하였다. 하지만, 현재까지의 돼지를 이용한 체지방 감소 항체 연구들은 항체 접종 시 돼지의 소화생리 등 영양생리학 적 안전성에 대한 연구는 매우 미흡한 실정이다. 특히 개발된 돼지 체지방 감소 후보항체의 산업화를 위해서는 실험처리로 발생할 수 있는 체내 영양생리학적 안전성을 확보하는 것은 반드시 선행되어 해결하여야 할 문제이다.

따라서, 본 연구는 체지방 감소 돼지고기 생산을 위해 개발한 복 강 및 피하지방 감소 후보 항체(Choi 등, 2010)를 이용하여 생체 주사 처리 시 돼지의 체중, 영양소의 분 소화율 및 혈핵대사물질에

* Corresponding author: Kyung Hoon Baek, Yeungnam University, Gyeongsan, 712-749, Korea. Tel: +82-53-810-3023, Fax: +82-53-8104769, E-mail: nuno@ynu.ac.kr 
미치는 영향을 조사하고자 실시되었다.

\section{재료 및 방법}

\section{1. 돼지 부위별 체지방 감소 후보 항체 생산}

본 연구에서는 Choi 등(2010)에 의해 발표된 돼지 부위별(복강 및 피하) 체지방 감소 항체를 후보 항체로 사용하였다. 간략하게 체지방 감소 항체 생산 방법을 설명하면 다음과 같다.

\section{(1) 돼지 지방세포 원형질막 단백질 분리}

Kestin 등 (1993)의 방법을 이용하여 돼지 복강 및 피하 지방세 포 원형질막 단백질을 분리하였다. 지방조직에서 혈관 및 결체조직 등을 최대한 제거하면서 가위로 잘게 세절한 후, digestion media (DMEM(Hyclone SH30243.01)， 0.1\% collagenase(Sigma, C6885), 30\% bovine serum albumin(BSA, Sigma A2153))와 지방의 비율을 2:1로 하여 shaking water bath에서 collagenase digestion $\left(42^{\circ} \mathrm{C} \quad 90 \mathrm{~min}\right)$ 을 실시하였다. Digestion 후 $37^{\circ} \mathrm{C}$ 서 5 분간 정치하여 미성숙한 지방세포들로 구성된 하층을 제거한 후 성 숙한 지방세포들을 선텍적으로 추출한 후 collagenase를 제거한 digestion media (washing media)로 2 3회 세척하여 순수한 지방 세포만을 추출하였다. Membrane extraction medium(MEM $0.25 \mathrm{M}$ sucrose, 0.01M Na $\mathrm{HPO}_{4}, 2 \mathrm{mM}$ EGTA, $200 \mathrm{ml}$ distilled water, $\mathrm{pH}$ 7.4)을 이용하여 지방세포를 파괴하고 중성지 방 층 제거 후, 하층액을 $4^{\circ} \mathrm{C} \quad 110,000 \times \mathrm{g}$ 에서 1 시간 동안 초고속 원심분리 하였다. 생성된 pellet을 $32 \%$ sucrose media와 함께 현 탁하고, 다시 원심분리 후 원심분리관에 생성된 단백질 밴드만을 따로 취하였다. Pellet의 량에 따라 적당랑의 MEM을 첨가한 뒤 DC Protein assay kit (Bio-rad 500-0116, USA)를 이용해 단백질 농도를 측정한 뒤, 항원으로 사용하였다. $\mathrm{AAb}$ 와 $\mathrm{SAb}$ 의 원형질막 단백질 패턴 차이는 최 등 (2008)에서 보고한 바와 같이 Quantityone (Bio-Rad, USA) program을 통해 matched test를 실시하여 분석하였으며, 그 결과는 choi 등(2009a)에서 제시한 바와 같다.

(2) 돼지 부위별 지방 특이 항체의 생산 및 역가 측정 돼지 부위별 지방 특이 후보 항체의 생산을 위한 면역주사는 Baek 등 (2005)의 방법에 따라 면양을 이용하여 실시하였다. 수컷 면양(Corriedale, 체중 $60 \mathrm{~kg}$ )의 피하 3 부위에 분리된 지방세포 원형질막 단백질을 면역주사 하였으며, 최초 면역주사 이후 결합력 이 증진된 높은 titer의 항체 생산을 위해 3 주 간격으로 2 차례 더 boosting 면역주사를 실시하였다. 1차 면역접종 전 면양의 경정맥 을 통해 혈액을 채취한 뒤 상온에서 1시간 정치시켜 혈액을 응고 시키고, $2,800 \mathrm{rpm}$ 에서 30 분간 원심분리 하여 비면역혈청을 분리 하였다. 또한, 마지막 면역접종이 끝난 후 12일째에 채혈한 후 비 면역혈청 분리 시와 동일한 방법으로 항혈청 (후보 항체)을 분리하 였다. 위의 방법으로 생산한 돼지 부위별 지방에 대한 항혈청들은
Kestin 등(1993)과 Choi 등(1997) 방법에 따라 $405 \mathrm{~nm}$ 에서 흡 광도를 측정하여 항체의 역가를 확인하였다. 본 연구에 사용된 항 체는 희석배율 $1: 1,000$ 배를 기준으로 비면역혈청은 항원- 체 결 합 반응이 거의 측정되지 않았으나, 복강 및 피하지방 항체 모두 $1: 16,000$ 배 희석배율까지 항원-항체 반응이 감지되어 본 연구에서 사용된 부위별 지방 특이 다클론 후보 항체가 지방세포 원형질막 단백질에 대해 매우 강한 역가를 가진 것으로 판단된다(Choi 등, 2010).

\section{2. 돼지 부위별 체지방 항체 처리}

Choi 등(2010)에서 개발한 복강 및 피하지방 후보 항체를 비거 세돈 12 두에 주사하여 주사 처리 전 및 주사 후 4주간 체중, 사료 섭취량, 분 소화율 및 혈액대사물질에 미치는 영향을 실시하였다 (Fig. 1).

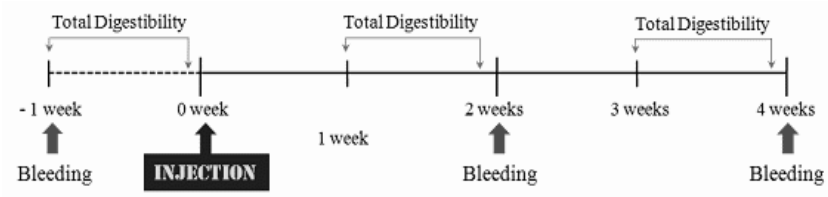

Fig. 1. Experiment outline for investigating the effects of immunization of antisera developed against abdominal or subcutaneous fats from pigs on fecal digestibility and blood metabolites.

\section{(1) 시험동물의 공시 및 사양관리}

공시축으로는 비거세돈 12 두(생후 약 5 개월령)를 처리구 당 3 두씩 4 처리구로 하였으며, 대조구 $(88.5 \pm 13.6 \mathrm{~kg}$, control), 비면 역혈청 처리구 $(89.4 \pm 9.6 \mathrm{~kg}, \mathrm{NAb})$, 복강항체 처리구 $(88.7 \pm 6.9$ $\mathrm{kg}, \mathrm{AAb})$ 및 피하항체 처리구 $(89.1 \pm 7.2 \mathrm{~kg}, \mathrm{SAb}))$ 로 구분배치 하였다. 음수는 자동급수기를 이용해 자유로이 섭취할 수 있도록 하였고, 기초사료는 NRC (1998) 요구량에 따라 배합한 옥수수두박 위주 사료로 생체중의 2.5\%를 일일 2회(09시 및 16시) 급여 하였으며, 시험사료 배합비는 table 1에 제시한 바와 같다. 영양소 의 분 소화율을 측정하기 위하여 시험기간 동안 분을 전량 수거하 였다. 시험동물의 사료섭춰량은 항체 주사 전 (0 week), 주사 후 2 주 및 4주(시험 종료)의 사료섭취량 측정기간 (7일)동안 매일 동일 한 시간(15시 30 분)에 측정하였고, 체중은 후보 항체 주사 전 $(0$ 주), 후보 항체 주사 후 $1,2,3$ 및 4주에 개체 별로 측정하였다.

(2) 체지방 항체 처리

$\mathrm{AAb}$ 및 $\mathrm{SAb}$ 에는 복강 및 피하지방 후보 항체를 $0.45 \mu \mathrm{m}$ filter 로 정제한 뒤 각각 사용하였으며, 주사는 정제된 후보 항체 $40 \mathrm{ml}$ 를 시험개시일 (0 day)에 등선을 따라 4 부위에 각각 $10 \mathrm{ml}$ 씩 피 하주사 하였다. Control은 주사처리를 하지 않았고, $\mathrm{NAb}$ 는 항원주 사를 하지 않은 면양의 혈액을 채취하여 혈청을 분리한 뒤 항체처 리구와 동일한 방법으로 주사 처리하였다. 
Table 1. Formula and chemical composition of the basal diets (\%)

\begin{tabular}{lr}
\hline Corn, yellow & 68.63 \\
Lupin & 8.06 \\
Wheat bran & 10.81 \\
Soybean meal (44.5\%) & 3.94 \\
Limestone & 0.86 \\
DCP & 0.23 \\
Salt & 0.30 \\
Soy oil & 2.50 \\
Molasses & 4.00 \\
Mineral mixture ${ }^{1)}$ & 0.25 \\
Vitamin mixture ${ }^{2)}$ & 0.25 \\
L-lysine-HCl & 0.17 \\
Total & 100.00 \\
\hline Chemical composition & \\
DE (kcal/kg) & 3,400 \\
CP (\%) & 11.50 \\
Lysine (\%) & 0.60 \\
Calcium (\%) & 0.45 \\
Phosphorus (\%) & 0.40 \\
\hline
\end{tabular}

${ }^{1)}$ Provided the following amouts per kilogram of diet : selenium $0.15 \mathrm{mg}$; manganese $0.03 \mathrm{~g}$; zinc $0.1 \mathrm{~g}$; iron $0.1 \mathrm{~g}$; iodine $0.5 \mathrm{mg}$; magnesium $0.1 \mathrm{~g}$.

${ }^{2)}$ Provided the following amounts per kilogram of diet : vitamin A 5,500 IU; vitamin $\mathrm{D}_{3} 550 \mathrm{IU}$; vitamin E $27 \mathrm{IU}$; menadione sodium bisulfate $2.5 \mathrm{mg}$; pantothenic acid $27 \mathrm{mg}$; niacin $33 \mathrm{mg}$; riboflavin $5.5 \mathrm{mg}$; vitamin $\mathrm{B}_{12} 0.04 \mathrm{mg}$; thiamin $5 \mathrm{mg}$; pyridoxine $3 \mathrm{mg}$; biotin $0.24 \mathrm{mg}$; folic acid $1.5 \mathrm{mg}$; choline chloride $700 \mathrm{mg}$.

${ }^{3)}$ Calculated value.

\section{3. 분 소화율 및 혈액대사물질 분석}

\section{(1) 분 소화율}

개발된 후보 항체의 돼지 체내 영양생리 대사 안전성 연구는 건 물, 조단백, 조지방, 조섬유 및 조회분의 분 소화율을 통해 확인하 였다. 분 소화율의 계산은 시험기간 동안 섭취한 사료의 양과 일반 성분 함량을 토대로 특정 영양성분의 섭취량을 계산한 후, 분으로 배설된 양과 분의 일반성분을 분석함으로서 섭취량과 배설량의 차 를 이용하여 계산하였다. 전술한 일반성분의 분석은 $\mathrm{AOAC}$ (1995)에 의거하여 분석하였다.

\section{(2) 혈액 대사물질 분석}

부위별 체지방 감소 후보 항체 주사 처리 전, 주사 후 2 주 및 4 주에 경정맥을 통해 각각 채혈을 실시하였다. 혈핵응고제 heparin 이 처리된 $10 \mathrm{ml}$ vacutainer (BD Vacutainer Systems Preanalytical Solutions, BD Vacutainer, USA)로 채혈한 후, 원심분리 ( $3,000 \mathrm{rpm}, 15$ 분)를 통해 혈장을 분리하여 분석 전까지 $-{ }^{\circ} \mathrm{C}$ 서 냉동보관 하였다. 본 연구에서는 혈핵 대사물질 중 사료영양소 의 이용 효율을 가늠할 수 있는 중요한 지표인 blood urea nitrogen (BUN), glucose, triglyceride (TG) 및 total cholesterol
(TC) 농도를 생화학 자동분석기(CIBA-Corning, Express Plus, USA)를 이용하여 분석하였다.

\section{4. 통계}

본 연구에서 도출된 사료섭취량, 분 소화율 및 혈핵 대사물질 결 과에 대한 실험구간 및 후보 항체처리 전 후 간 통계분석은 SAS 통계 package (2002)에 포함된 일반선형모형 (GLM procedure)를 이 용하여 분산분석을 실시하였으며, 유의성 검증은 Duncan (1955)의 다중검정법으로 $95 \%$ 신뢰수준에서 검증하였다.

\section{결과 및 고찰}

\section{1. 돼지 부위별 체지방 감소 항체 생산}

본 연구의 주 목적인 돼지 부위별 체지방 감소 항체의 생체 주 사 시 사료섭취량, 분 소화율 및 혈액 대사물질에 미치는 영향을 탐색하기 위해 생산된 후보 항체는 기 발표(Choi 등, 2010)된 바 와 같이 높은 항체의 억가를 나타내었음은 물론 in vitro 시험을 통해 타장기 안전성 억시 확인하였다. 또한, in vitro 세포배양을 통해 지방세포에 대해 매우 강한 결합력(파괴효과)을 가진 항체임 을 확인하였다(see Choi 등, 2010). 따라서, 본 고에서는 항체 개 발관련 결과 및 고찰은 생략하기로 한다.

\section{2. 체중 및 사료섭취량}

본 연구에서 돼지에 직접적으로 주사 처리된 $\mathrm{AAb}$ 및 $\mathrm{SAb}$ 에 대 한 공시축의 체중 변화는 Fig. 2와 같다. Fig. 2에 나타난 바와 같 이 체중은 항체주사 전 $(0$ week), 항체 주사 후 1 주 간격으로 측 정하였다. 시험 종료 시점(4주)을 기준으로 볼 때, 평균 체중으로 보면 후보 항체의 처리로 인한 돼지의 성장에 특별한 차이는 없는 것으로 확인되었다 $(\mathrm{P}>0.05)$. 다만, 전 기간에 걸쳐 수치적 증가를

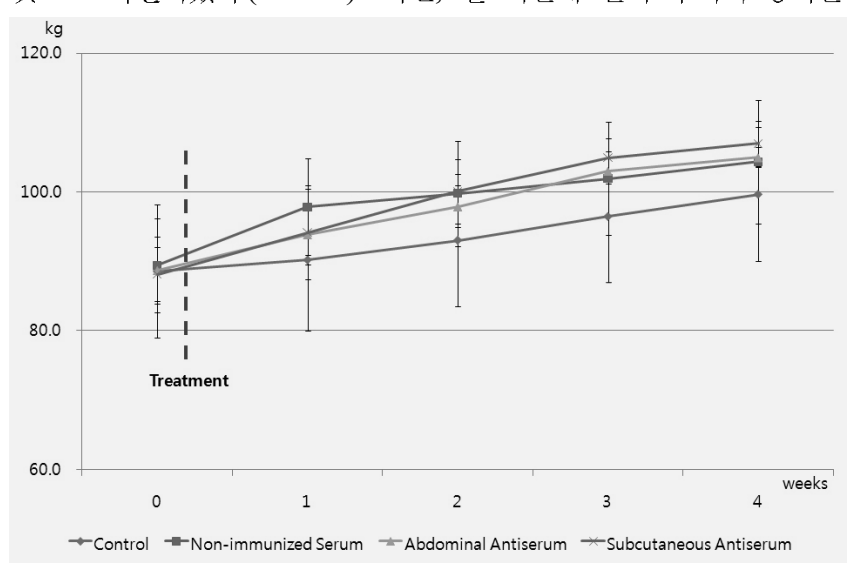

Fig. 2. Effect of immunization of antiserum developed against abdominal or subcutaneous fats on the change of body weight of pigs. 
나타나는 것은 돼지의 일반적인 성장에 기인하는 것으로 판단된다. 비록 통계적 유의성은 없었으나, 후보 항체 주사 후 항체처리구의 1 주째 체중 증가는 비교적 완만한데, 이것은 항체 주사로 인한 일 시적인 현상으로 한우를 이용한 최근 연구(Choi 등, 2009b) 및 흰쥐 연구(Baek과 Choi, 2002)의 결과와 유사하였다. 특이한 점 은 비록 통계적인 유의 차는 없었으나 control의 체중이 시험종료 시점까지 가장 낮은 것으로 나타났는데, $\mathrm{NAb}$ 의 체중으로 미루어보 아 $\mathrm{AAb}$ 및 $\mathrm{SAb}$ 처리구에서 나타난 체중의 증가효과는 항체에 의 한 성장효과라고 보기엔 무리가 있으며, 시험축 개체간의 차이에서 비롯된 것으로 추측된다. Baek 등 (2007)은 돼지를 이용한 다클론 항체 개발 및 특성에 관한 연구에서 돼지 지방세포 원형질막 단백 질에 대한 항혈청은 돼지의 체중에 특이한 영향을 미치지 않는다고 보고하여 본 연구의 결과와 유사한 결과를 보고하였다. 다른 축종 인 한우의 경우도 부위별 지방감소 후보항체가 성장에 특별한 영향 을 미치지는 않는다고 보고하였다(Choi 등, 2009b).

Fig. 3은 돼지 불가식 체지방 감소 후보 항체의 in vivo 안전성 연구 결과 중 사료섭취량의 변화를 측정한 것이다. 사료섭취량은 시험 전 $(0$ week $)$, 주사 후 2 주(2 weeks) 및 시험 후 4 주 $(4$ weeks) 시점에 각 7일씩 측정하였다. Fig. 3에 나타난 바와 같이 시험돈들의 사료섭취량은 주사의 처리 및 후보 항체의 처리로 인한 특별한 차이를 나타네지 않는 것으로 확인되었다. 다만, 각 처리구 들의 사료섭취량은 시험 전과 비교해서 시험 4주, 즉 시험 종료 시 점에서 수치적 증가(control 및 $\mathrm{NAb}$ ) 또는 유의적 증가(AAb 및 $\mathrm{SAb}, \mathrm{P}<0.05)$ 가 나타났는데, 이는 시험돈의 체중 증가에 의한 사 료의 제한급여량(시험돈 체중의 $2.5 \%$ 급여)이 증가한 결과로 판단 된다. 역으로 생각하면, 2 주 차의 사료섭춰량 변화가 없는 것이 오 히려 후보 항체로 인한 사료섭취량의 감소로 추측할 수 있으나, control 및 NAb의 사료섭취량도 크게 변화가 없는 것으로 보아 체중 측정, 혈액체취 등의 적응으로 인한 일시적인 현상으로 사료 된다. 한편, 대다수의 항체관련 in vivo 연구결과 (Futter 등, 1992 Kestin 등, 1993; Flint, 1998 Monoley 등, 2002)에서 항체 주사 직후 항체처리구의 사료섭취량이 감소되는 결과들을 보고하였는데, Futter 등 (1992)은 흰줘 지방세포 감소 항체를 처리한 경우 사료 섭취량 및 체중 감소를 보고하였고, Flint(1998)는 대조구 대비 $40 \%$ 의 사료섭취량 감소가 있었다고 보고하였다. 국내의 경우 한우 (Choi 등, 2009b) 및 흰쥐(Baek과 Choi, 2002)에 있어서 항체 처리 시 일시적인 사료섭춰량 감소를 보고하였다. 본 시험에서는 2 주 간격으로 사료섭취량 측정기간을 따로 두고 사료섭취량을 측정 하였기 때문에 특이적으로 사료섭취량이 감소하는 효과를 확인하지 못했다. 하지만 전술한 후보 항체 주사 후 사료섭취량이 감소하는 국내 외 in vivo 시험 결과들 또한 사료섭취량 감소가 매우 일시 적인 것으로 시간 경과에 따라 사료섭취량이 회복되어 시험 종료 시에는 대조구들의 사료섭취량과 비교 시 차이가 나타나지 않아, 이는 본 연구의 결과와 일치한다. 따라서 현재까지의 결과들로 미 루어보아, 본 연구에서 개발된 돼지 $\mathrm{AAb}$ 및 $\mathrm{SAb}$ 들은 시험돈의 체중 및 사료섭취량에 특이한 영향을 미치지 않는 안전한 항체로

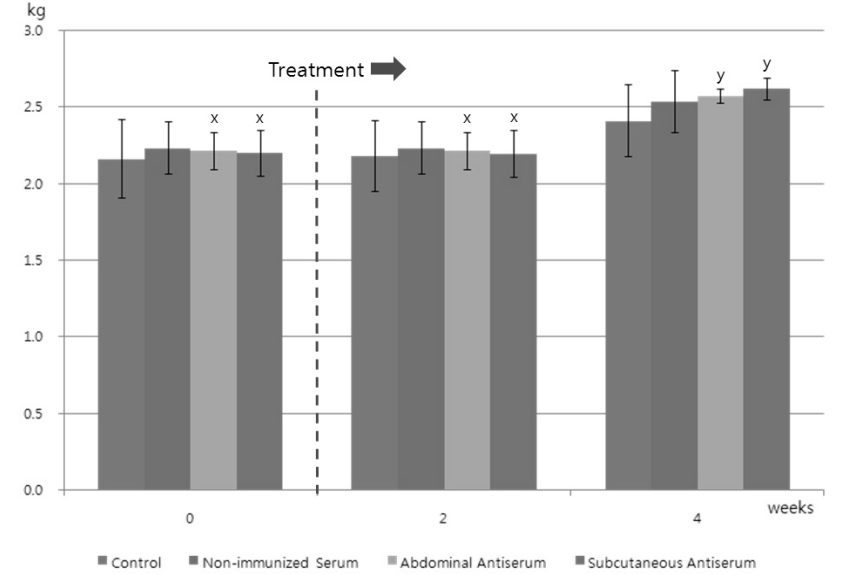

Fig. 3. Effect of immunization of antiserum developed against abdominal or subcutaneous fats on feed intake of pigs. Mean \pm S.E. $(n=3)$. Values with different letters $\mathrm{x}$ or $\mathrm{y}$ are different between 3 times $(0,2$, and 4 weeks) by the same group $(\mathrm{P}<0.05)$.

판단된다.

\section{3. 영양생리 안전성}

현재까지 돼지를 대상으로 체지방 감소를 위한 지방세포 다클론 항체 주사 처리 시 분 소화율 등 영양생리대사에 미치는 영향에 대 한 연구는 본 연구가 최초이다. 따라서, 기존 연구 결과와 현재 결 과와의 비교 및 고찰은 불가능하였으며, 다만 일반적인 사료 급여 시 나타나는 영양생리적 반응 수준 등에 대한 기존의 연구와 최근 한우를 대상으로 실시한 항체의 영양생리적 안전성 연구(Choi 등, 2009b) 등을 중심으로 비교하여 현재 개발된 후보 항체에 대한 생 체 영양생리 안전성 유무를 고찰하였다.

(1) 분 소화율

Fig. 4는 항체의 처리가 돼지의 분 소화율에 특이한 영향을 미치 는가를 확인해보기 위해 실시한 분 소화율 측정결과이다. 건물, 조 단백질, 조지방 및 조섬유의 분 소화율은 후보 항체 주사 전, 후 및 시험구 간의 통계적 유의성이 나타나지 않았다 $(\mathrm{P}>0.05)$. 조회 분 소화율의 경우 주사 후 2주째 control에서 감소를 및 4주째 $\mathrm{NAb}$ 에서 증가를 보였는데 $(\mathrm{P}<0.05)$, 항체 처리구가 아니라는 점에 서 이것은 실험 또는 분석상의 오차에서 기인한 것으로 판단된다. 시험구 간의 비교에서 주사 후 4 주째 $\mathrm{AAb}$ 및 $\mathrm{SAb}$ 에서 수치적 $(\mathrm{P}>0.05)$ 또는 통계적 감소 $(\mathrm{P}<0.05)$ 를 보였는데, 주사 처리 전인 0 주 및 2 주에서도 매우 유사한 패턴을 보이는 바, 항체처리에 의한 영향보다는 개체 간의 차이에서 기인한 결과로 사료된다. 일반적으 로 단위동물의 소화율은 섭취사료의 종류 및 외부 첨가제 등에 따 라 영향을 받는 것으로 알려져 있는데(Sauer 등, 1991; Scheuermann, 1993; Hong and Lindberg, 2007), 본 연구에서 

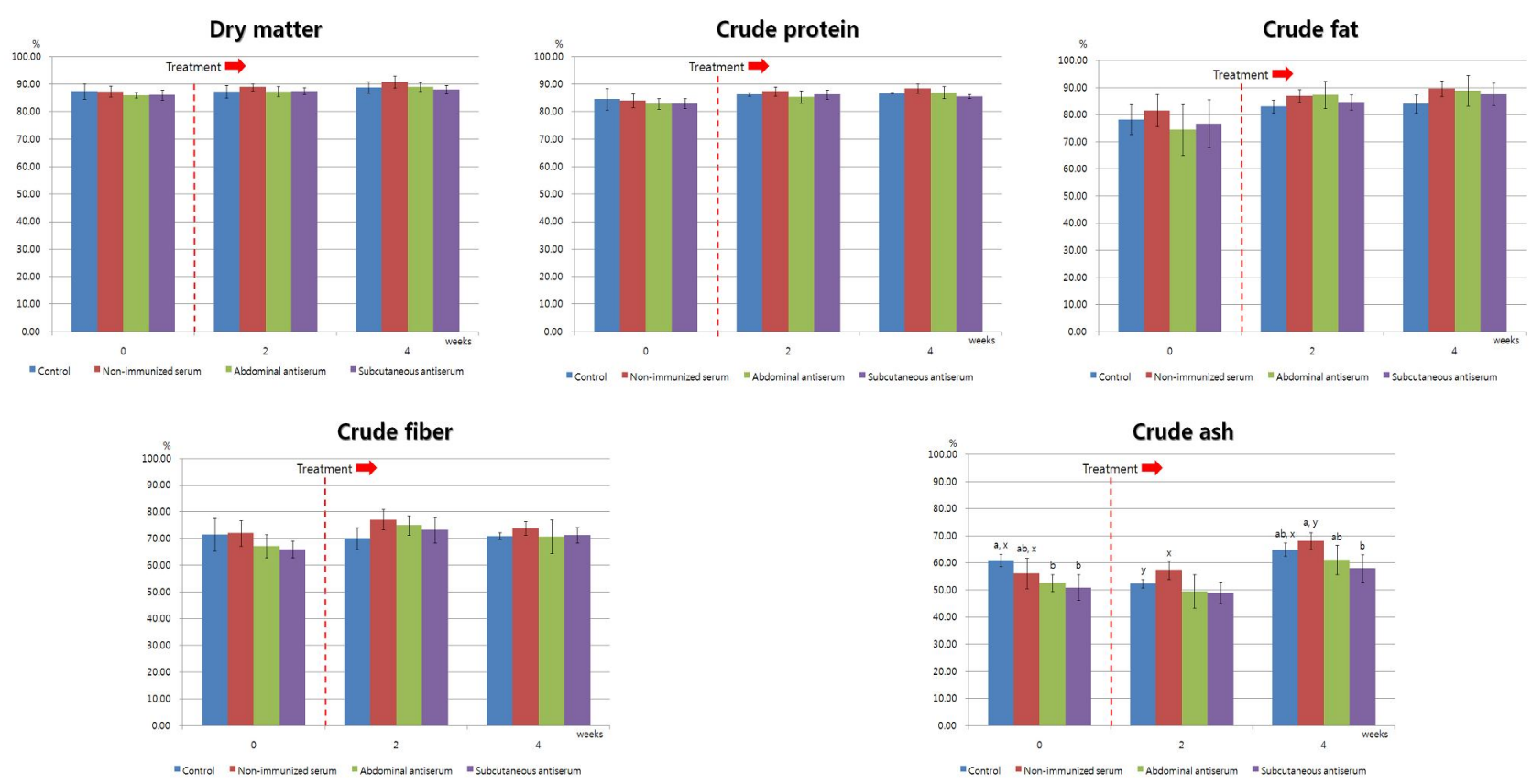

Fig. 4. Effect of immunization of antiserum developed against abdominal or subcutaneous fats on fecal digestibility of dry matter, crude protein, crude fat, crude fiber and crude ash in pigs. Mean $\pm S . E$. $(n=3)$. Values with different letters $a$ or $b$ are different between 4 groups within the same time and $\mathrm{x}$ or $\mathrm{y}$ are different between 3 times $(0,2$, and 4 weeks) by the same group $(P<0.05)$.

항체의 처리가 돼지의 분 소화율에 영향을 미치지 않았다는 사실은 후보 항체가 돼지의 영양생리대사에 특이한 영향을 미치지 않는다 고 판단된다.

\section{(2) 혈액 대사물질}

혈액 대사물질 변화는 가축의 영양소 이용과 대사를 직접적으로 측정하여 비교함으로써 시험처리(사료, 첨가제, 항체주사 등)로 인 한 영향을 알 수 있어 체중, 사료섭취량, 영양소의 분 소화율 등과 함께 영양생리 연구에 있어서 매우 중요한 지표이다(Kwon 등, 2005; Raghuvansi 등, 2006). Fig. 5 8는 항체의 주사 처리에 의 한 돼지 혈액 내 BUN, glucose, TG 밎 TC 농도 변화를 나타낸 것이다. 혈 중 $\mathrm{BUN}$ 함량은 시험종료 시점인 주사 후 4주에서 $\mathrm{AAb}$ 및 $\mathrm{SAb}$ 유의적으로 $(\mathrm{P}<0.05)$ 증가하는 것으로 나타났다 (Fig. 5). 일반적으로 BUN의 증가는 단백질의 체내 이용성이 개선 되어 단백질의 흡수율이 증가된 것으로 해석할 수 있다(Enright 등, 1990). 실제 항체를 처리한 처리구에서 지방세포의 파괴와 동 시에 단백질 합성이 보상적으로 일어난다는 보고(Futter와 Flint, 1987; Panton 등, 1990)들이 있다. 하지만, 본 연구에서 나타난 증가는 후보 항체 주사 전 $(0$ 주) 및 주사 후2주에서도 유의적 $(0$ 주) 또는 수치적으로(2주) 유사한 패턴이 나타난 것으로 볼 때, 항체 처리에 의한 차이보다는 개체간의 차이로 인한 현상으로 사료되어 BUN 함량의 결과만으로는 보상성장이 일어났다고 판단하기 어렵 다. 따라서, 향후 개발된 지방 감소 후보항체의 in vivo 효과 시험 시 단백질 보상성장 유무에 대해서도 자세하게 조사되어야 할 것으
로 생각된다. 한편, 주사 전을 기준으로 볼 때, 주사 후 4 주차의 모든 시험구에서 유의적으로 $\mathrm{BUN}$ 감소 $(\mathrm{P}<0.05)$ 가 나타났다. 하 지만, 이것 역시 후보 항체 처리구 뿐만 아니라, control 및 NAb 구의 BUN 함량도 감소되는 것으로 보아 항체보다는 시험 진행 및 샘플링에서 기인된 영향으로 판단된다. 전 시험구의 BUN 농도

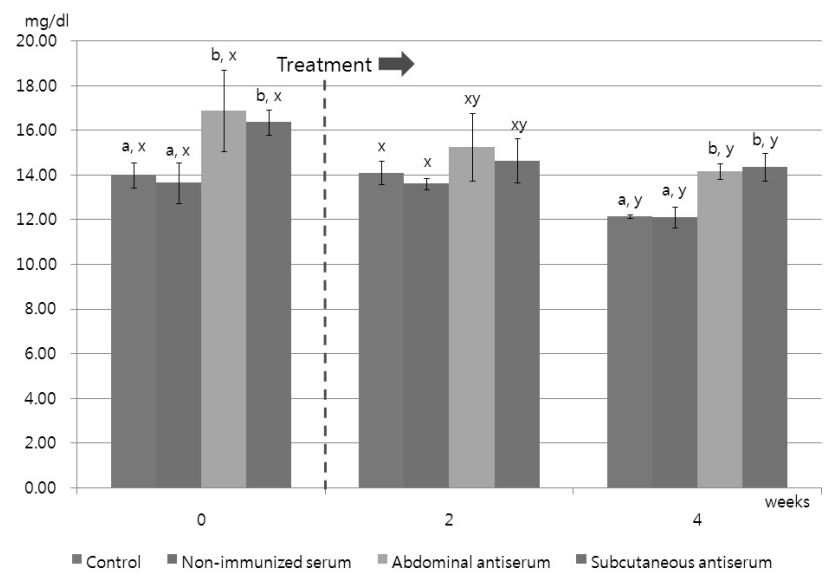

Fig. 5. Effect of immunization of antiserum developed against abdominal or subcutaneous fats on blood urea-N concentration in pigs. Mean \pm S.E. $(n=3)$. Values with different letters $a$ or $b$ are different between 4 groups within the same time and $x$ or $y$ are different between 3 times $(0,2$, and 4 weeks) by the same group $(P<0.05)$. 


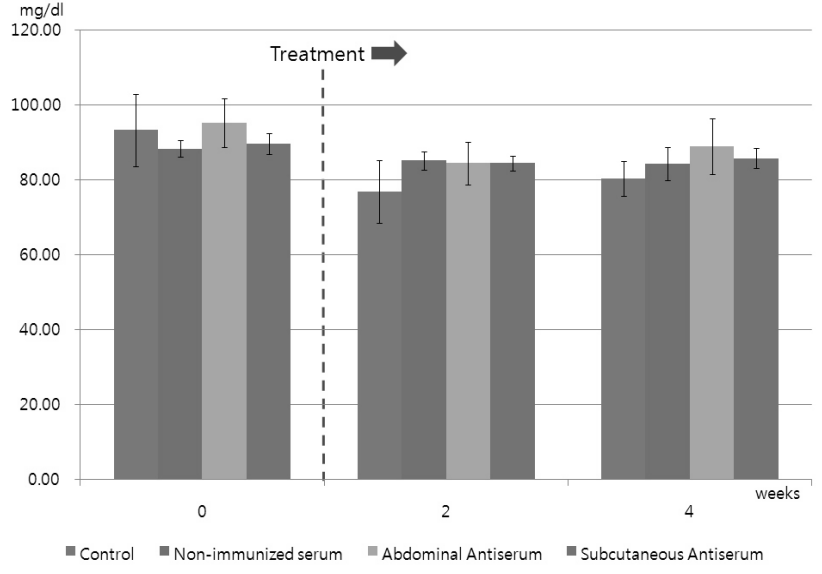

Fig. 6. Effect of immunization of antiserum developed against abdominal or subcutaneous fats on plasma glucose concentration in pigs. Mean \pm S.E. $(n=3)$.

$(12.1 \sim 16.9 \mathrm{mg} / \mathrm{dl})$ 는 기존 연구에서 일반적인 사료 급여 시 나타 나는 비육돈의 BUN 평균 농도 범위에서 크게 벗어나지 않는 것으 로 나타났다 (Kook 등, 2005; Kim 등, 2006; Park 등, 2006).

Fig. 6은 항체의 처리로 인한 돼지 혈장 내 glucose 함량의 변 화를 나타낸 것이다. 돼지 혈 중 glucose 수준은 항체 주사 전, 주 사 후 2 주 및 4주 경과 시까지 유의적 차이를 나타내지 않았다 (P $>0.05$ ). 또한, 동일한 시간 (week) 대 시험구 간의 glucose 함량에 서도 통계적 유의성이 나타나지 않았다. 다만, 주사 후 2주째 control에서 나타난 glucose 농도의 수치적 감소는 특별한 외부 영 향이 없었던 무처리구이었기 때문에 혈핵 채취 등으로 인한 오차 또는 시험축들의 개체 차에 기인한 것으로 판단된다. 이러한 결과 는 후보 항체의 처리로 인하여 파괴된 지방세포에서 유리되는 TG 의 대사로 인하여 혈중 glucose 농도가 증가할 것이라는 예상과는 다소 상이한 결과이다. Moloney 등 (1998)은 흰쥐를 이용한 지방 감소 항체 연구에서 혈중 glucose 농도에 변화가 없었다고 보고하 였으며, 한우에 있어서도 본 연구 결과와 유사하게 부위별 지방 감 소 후보항체 처리 시 혈액 내 glucose 농도에는 영향을 미치지 않 는다고 보고하였다(Choi 등, 2009b). 한편, 기존 연구에서 돼지를 이용한 일반적인 사료 급여와 비교했을 때 본 시험에 사용된 시험 축들의 glucose 농도 $(76.8 \sim 95.3 \mathrm{mg} / \mathrm{dl})$ 는 모두 정상 수준이었다 (Kook 등, 2005 Park 등, 2006).

Fig. 7은 후보 항체 주사 처리가 혈액 내 $\mathrm{TG}$ 농도에 미치는 영 향을 보여주고 있다. 혈액 내 TG 농도는 동일한 시간(week) 내 시험구 간 유의적인 차이는 나타나지 않았다 $(\mathrm{P}>0.05)$. 항체 주사 전 $(0$ 주)과 비교해서 주사 후 2 및 4 주에서 유의적 (control, $\mathrm{NAb}$ 및 $\mathrm{AAb} ; \mathrm{P}<0.05)$ 및 수치적으로 $(\mathrm{SAb}, \mathrm{P}>0.05)$ 증가를 보였다. 이것은 돼지 체내 지방세포가 항체에 의해서 파괴되어 유리된 $\mathrm{TG}$ 에 의해 기인되었다고 추측될 수 있지만(Baek과 Choi, 2002), 전 술한 바와 같이 시험구 간 $\mathrm{TG}$ 농도의 유사한 패턴과 혈 중 glucose 농도에서 유의적 증가가 없었던 것으로 보아 단순히 후보

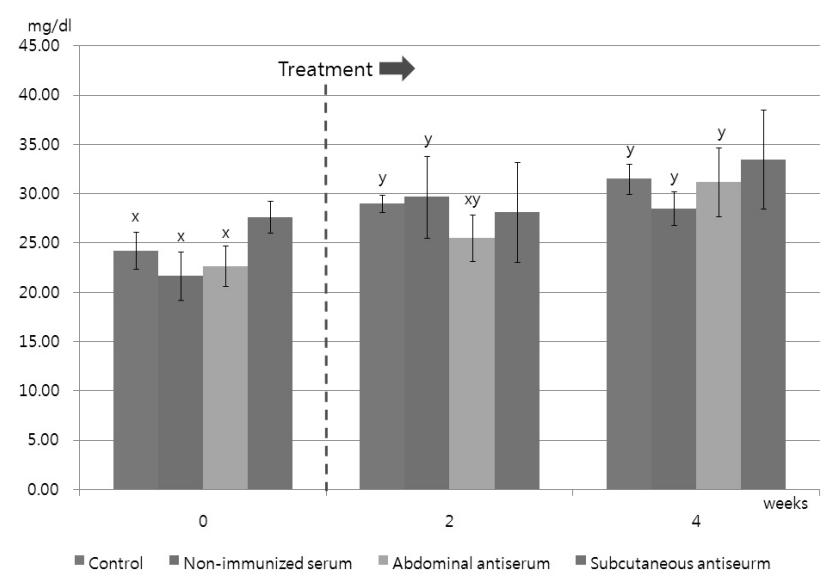

Fig. 7. Effect of immunization of antiserum developed against abdominal or subcutaneous fats on plasma triglyceride concentration in pigs. Mean \pm S.E. $(n=3)$. Values with different letters $x$ or $y$ are different between 3 times $(0,2$, and 4 weeks) by the same group $(P<0.05)$.

항체에 의한 증가라고 판단할 수는 없다. 다만, Choi 등(2009b)의 연구에서 항체 처리 시 혈중 glucose 농도의 증감에는 영향을 주 지 않으면서도 혈액 내 $\mathrm{TG}$ 의 수치적 증가가 나타난 것으로 볼 때, 향후 항체에 의한 돼지 in vivo 체지방 함량 연구 시 좀더 추가적 인 고찰이 필요할 것으로 생각된다.

Fig. 8은 후보 항체 주사 처리가 혈액 내 TC 농도에 미치는 영 향을 나타내고 있다. 항체 주사 전 ( 0 주)과 비교해서 혈액 내 $\mathrm{TC}$ 농도는 주사 후 2 주에서는 유의적인 차이는 나타나지 않았고 $(\mathrm{P}>$ $0.05)$, 주사 후 4 주에서는 $\mathrm{AAb}$ 및 $\mathrm{SAb}$ 에서 유의적 감소 $(\mathrm{P}<$ 0.05 )를 보였다. 같은 시간(week) 내 시험구 간 $\mathrm{TC}$ 농도는 control에 비해 유의적인 $(\mathrm{P}<0.05)$ 감소를 보였다. 비록 항체 주사

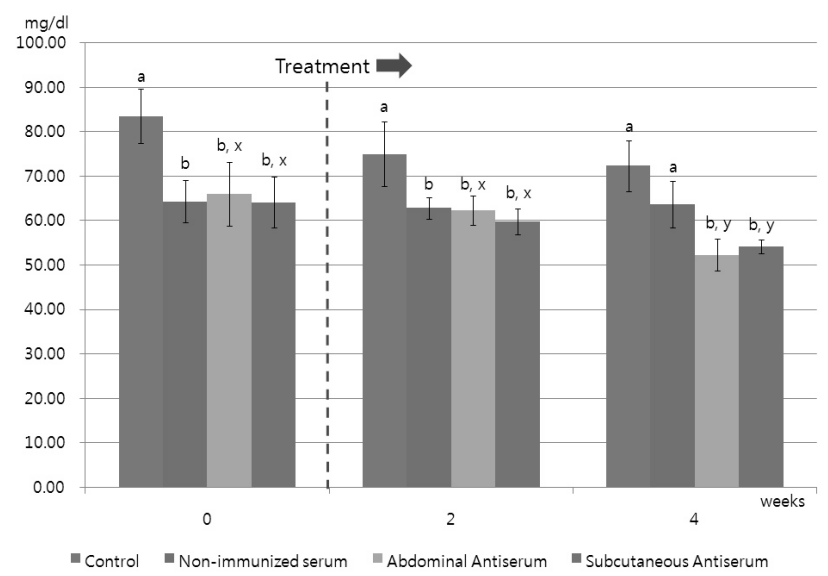

Fig. 8. Effect of immunization of antiserum developed against abdominal or subcutaneous fats on plasma total cholesterol concentration in pigs. Mean $\pm S . E$. $(n=3)$. Values with different letters a or $b$ are different between 4 groups within the same time $(P<0.05)$. 
전에서 시험구 간 유사한 패턴이 나타나 $\mathrm{TC}$ 농도 감소와 체지방량 감소의 관련성을 명확히 설명하긴 어렵지만, 혈핵 내 $\mathrm{TC}$ 농도는 체내 지방침착도 및 도체 지방량과 양의 밀접한 관계가 있음을 고 려할 때(Wheeler 등, 1987; Early 등, 1990), 추가적인 in vivo 시험이 필요할 것으로 사료된다. 한편, 본 연구에서의 $\mathrm{TC}$ 농도 $(52.3 \sim 83.5 \mathrm{mg} / \mathrm{dl})$ 는 기존 연구에서 일반적인 단위동물의 혈액 내 TC농도와 유사한 수준이었다(Park 등, $2006 \mathrm{Cui}$ 등, 2008).

이상의 결과를 종합해보면, 본 연구에서 이용된 돼지 복강 및 피 하 체지방 감소 후보 항체는 in vitro (Choi 등, 2010) 뿐만 아니 라 in vivo 영양생리대사에 부정적 영항을 미치지 않는 안전한 항 체로 판단된다.

\section{요 약}

본 연구는 비거세돈 12 두를 이용하여 돼지 복강 및 피하지방 감 소 후보 항체를 생체 주사 처리 시 체중, 분 소화율 및 혈액 대사 물질 등 영양생리대사에 미치는 영향을 조사하고자 실시하였다. Choi 등(2010)에서 개발된 돼지 복강 및 피하지방 감소 후보 항 체를 피하 주사하였을 때 주사 후 4주까지 평균 체중은 수치적 증 가가 발생했으나 $(\mathrm{P}>0.05)$, 전 기간에 걸쳐 수치적 증가를 보여 항 체의 처리로 인한 영향보다는 돼지의 일반적인 성장에 기인하는 것 으로 판단된다. 항체 주사 처리 시 건물, 조단백질, 조지방 및 조섬 유의 분 소화율은 항체 주사 전, 후 및 시험구 간의 통계적 유의성 이 나타나지 않았다 $(\mathrm{P}>0.05)$. 조회분 소화율의 경우 항체 주사 후 2주째 control에서 감소를 및 4주째 NAb에서 증가를 보였으나(P $<0.05), \mathrm{AAb}$ 및 $\mathrm{SAb}$ 에서는 유의적 변화가 없었다. 혈핵 대사물 질의 변화에서는 항체 주사 후 4주의 $\mathrm{AAb}$ 및 $\mathrm{SAb}$ 에서 $\mathrm{BUN}$ 농 도가 유의적으로 증가하는 것으로 나타났다 $(\mathrm{P}<0.05)$. 하지만, 후보 항체 주사 전에서도 유사한 패턴으로 유의적 증가를 보여 항체 처 리에 의한 차이보다는 개체간의 차이로 사료된다. 혈액 내 glucose 및 $\mathrm{TG}$ 농도는 후보 항체 처리에 의한 유의적 차이는 나타나지 않 았다 $(\mathrm{P}>0.05)$. 체지방 함량과 밀접한 관계에 있는 혈액 내 $\mathrm{TC}$ 농 도에서는 control 대비 후보 항체 주사 후 4주차 $\mathrm{AAb}$ 및 $\mathrm{SAb}$ 에 서 유의적 감소가 나타나 $(\mathrm{P}<0.05)$, 체지방 감소가 일어나고 있음 을 간접적으로 추론할 수 있다. 이상의 결과를 볼 때, 본 연구에서 이용된 $\mathrm{AAb}$ 및 $\mathrm{SAb}$ 는 in vivo 영양쟁리대사에 부정적 영향을 미 치지 않는 안전한 항체로 판단된다.

Key words : 돼지, 다클론 항체, 분 소화율, 혈액 대사물질, 지방

\section{감사의 글}

본 연구는 농촌진훙청 공동연구사업 수행결과의 일부로 연구비 지원에 감사 드립니다.

\section{인 용 문 헌}

AOAC. 1995. Official method of analysis. $15^{\text {th }}$ edition. Association of Official Analytical Chemist, Washington DC.

Baek, K. H. and Choi, C. B. 2002. Effects of polyclonal antiserum against adipocyte plasma membrane proteins on body composition of passively immunized Sprague-Dawley male rats. J. Anim. Sci. \& Technol. (Kor.) 44:39-44.

Baek, K. H., Choi, C. W., Choi, C. B. and Lee, B. S. 2007. Passive immunization approach to reduce body fat in pigs using fat-specific polyclonal antiserum. Asian-Aust. J. Anim. Sci. 20: 1594-1599.

Baek, K. H., Kwak, T. H., Oh, Y. S., Choi, C. W., Jung, K. K. and Choi, C. B. 2005. Studies on the development and utilization of polyclonal antibodies against swine adipocyte plasma membrane proteins. J. Anim. Sci. \& Technol. (Kor.) 47:19-28.

Choi, C. B., Lee, M. J. and Kwon, E. J. 1997. Development of polyclonal antibody to adipocyte plasma membrane proteins isolated from Korean Naive Cattle. Korean J. Anim. Sci. 39: 669-674.

Choi, C. B., Lee, M. J. and Kwon, E. J. 1998. Production of polyclonal antibodies specific to procine adipocyte plasma membrane proteins in sheep. Korean J. Biomed. Lab. Sci. 4: 57-63.

Choi, C. B. and Lee, S. R. 1996. Studies on the production of lean pork by immunological approach - Development of antibodies to porcine adipocyte plasma membrane. Korean J. Anim. Sci. 38:369-374.

Choi, C. W., Baek, K. H., Choi, C. B., Oh, Y. K. and Hong, S. K. 2010. Development of polyclonal antibodies to abdominal and subcutaneous adipocytes for producing fat-reduced high quality pork. Korean J. Food Sci. Ani. Resour. 30(1):87-94.

Choi, C. W., Baek, K. H., Kim, S. J., Cho, S. B., Park, J. C., Kim, I. C., Kim, S. H., Ji, S. Y. and Choi, C. B. 2009a. Screening of specific protein binding to antibody against adipocyte plasma membrane proteins of pig. 한국동물자원과학희 학술발표회. PF29024. pp. 173

Choi, C. W., Baek, K. H., Kim, S. J., Oh, Y. K., Hong, S. K., Kwon, E. K., Song, M. K. and Choi, C. B. 2009b. Effects of polyclonal antibodies to abdominal and subcutaneous adipocytes on ruminal fermentation patterns and blood metabolites in Korean native steers. J. Anim. Sci. \& Technol. (Kor.). 51: 231-240.

Choi, C. W., Kim, Y. H., Kim, S. J., Song, M. K., Kwon, E. K., Oh, Y. K., Hong, S. G. Choi, S. H. and Baek, K. H. 2008. Development of polyclonal antibodies to abdominal and subcutaneous adipocytes for fat-reduced Hanwoo beef production. Korean J. Food Sci. Ani. Resour. 28:651-659.

Cui, X. S., Kim, H. I. and Cho, S. K. 2008. Effect of the water 
soluble extracts from velvet antler on lipid metabolism and blood components in rats. J. Anim. Sci. \& Technol. (Kor.). 50:417-428.

Duncan, D. B. 1955. Multiple range and multiple F test. Biometrics. 11:1-42.

Early, R. J., McBride, B. W. and Ball, R. O. 1990. Growth and metabolism in somatotropin-treated steers : 1. Growth, serum chemistry and carcass weights. J. Anim. Sci. 68:4134-4143.

Enright, W. J., Quirke, J. F., Gluckman, P. D., Breier, B. H., Kennedy, L. G., Hart, I. C., Rochecoert, J. F. and Allen, P. 1990. Effects of long-time administration of pituitary-derived bovine growth hormone and estradiol on growth in steers. J. Anim. Sci. 68:2345-2356.

Flint, D. J., Coggrave, H., Futter, C. E., Gardner, M. J. and Clarke, D. J. 1986. Stimulatory and cytotoxic effects of an antiserum to adipocyte plasma membranes on adipose tissue metabolism in vitro and in vivo. Int. J. Obes. 10:69-77.

Flint, D. J. 1998. Effects of antibodies to adipocytes on body weight, food intake, and adipose tissue cellularity in obese rats. Biochem. Biophys. Res. Commun. 252:263-268.

Futter, C. E. and Flint, D. J. 1987. Long-term reduction of adiposity in rats after passive immunization with antibodies to rat fat cell plasma membranes. In: E. M. Berry, S. H. Blondheim, H. E. Eliahon and E. Shafrir(Ed.). Recent Advances in obesity research: V. in Proc. 5th Int. Congr. on Obesity, Sept. 14-19, 1986, Jerusalem, Israel. p181. John Libbey and Company, London.

Futter, C. E., Panton, D., Kestin, S. and Flint, D. J. 1992. Mechanism of action of cytotoxic antibodies to adipocytes on adipose tissue, liver, and food intake in the rat. Int. J. Obes. Relat. Metab. Disord. 16(8):615-622.

Hong, T. T. and Lindberg, J. E. 2007. Effect of guar gum on nitrogen secretion into isolated loops of jejunum in conscious growing pigs. Br. J. Nutr. 52:499-505.

Kestin, S., Kennedy, R., Tonner, E., Kiernan, M., Cryer, A., Griffin, H., Butterwith, S., Rhind, S. and Flint, D. J. 1993. Decreased fat content and increased lean in pigs treated with antibodies to adipocyte plasma membranes. J. Anim. Sci. 71, 1486-1494.

Kim, H. J., Min, B. J., Cho, J. H., Chen, Y. J. Yoo, J. S., Kim, I. H., Jang J. S. and Lee, Y. K. 2006. Effects of mud flat bacteria origin protease supplementation on growth performance, amino acid digestibility, blood characteristics, meat quality, fecal VFA and $\mathrm{NH}_{3}-\mathrm{N}$ concentration in finishing pigs. J. Anim. Sci. \& Technol. (Kor.) 48:49-58.

Kook, K., Jeong, J. H. and Kim, K. H. 2005. The effects of supplemental levels of bamboo vinegar liquids on growth performance, serum profile, carcass grade, and meat quality characteristics in finishing pigs. J. Anim. Sci. \& Technol. (Kor.) 47:721-730.
Kwon, E. G., Hong, S. K., Seong, H. H., Yun, S. G., Park, B. K., Cho, Y. M., Cho, W. M., Chang, S. S., Shin, K. J. and Paek, B. H. 2005. Effects of ad libitum and restricted feeding of concentrates on body weight gain, feed intake and blood metabolites of Hanwoo steers at various growth stages. J. Anim. Sci. \& Technol. (Kor.) 47:745-758.

Moloney, A. P. 1995. Immunomodulation of fat deposition. Livest. Prod. Sci. 42:239-245.

Moloney, A. P., Allen, P. and Enright, W. J. 1998. Passive immunizationof sheep against adipose tissue: effects on metabolism, growth and body composition. Livest. Prod. Sci. 56:233-244.

Moloney, A. P., Moore, W. and Allen, P. 1994. Decreasing body fat by passive immunisation against adipose tissue. J. Anim. Sci. 72 (suppl. 1):364.

Moloney, A. P., Allen, P. and Enright, W. J. 2002. Body composition and adipose tissue accretion in lambs passively immunised against adipose tissue. Livest. Prod. Sci. 74:165-174.

Panton, D., Futter, C., Kestin, S. and Flint, D. 1990. Increased growth and protein deposition in rats treated with antibodies to adipocytes. Am. J. Physiol. 258:E985-9.

Park, J. C., Kim, Y. H., Jung, H. J., Lee, S. D., Jang, H. D., Kim, I. C., Lee, S. J., Lee, J. J., Lee. C. H. and Lee, S. S. 2006. Effects of dietary supplementation of cultured wild-ginseng powder or its fermented culture byproducts on growth performance and carcass parameters in finishing pigs. J. Anim. Sci. \& Technol. (Kor.) 48:819-826.

Raghuvansi, S., Tripathi, M., Mishra, A., Chaturvedi, O., Prasad, R., Saraswat, B. and Jakhmola, R. 2006. Feed digestion, rumen fermentation and blood biochemical constituents in Malpura rams fed a complete feed-block diet with the inclusion of tree leaves. Small Rumin. Res. 71:21-30.

SAS. 2002. SAS User's Guide, Statistics, Version 9.1 Ed. SAS Inst., Inc., Cary, NC.

Sauer, W. C., Mosenthin, R., Ahrens, F. and den Hartog, L. A. 1991. The effect of source of fiber on idea and fecal amino acid digestibility and bacterial nitrogen excretion in growing pigs. J. Anim. Sci. 69:4070-4077.

Scheuerermann, S. E. 1993. Effect of the probiotic Paciflor (CIP5832) on energy and protein metabolism of growing pig. Anim. Feed Sci. Technol. 41:181-186.

Wheeler, T. L., Davis, G. W., Stoecker, B. J. and Harmon, C. J. 1987. Cholesterol concentration of longissimus muscle, subcutaneous fat and serum of two beef cattle breed types. J. Anim. Sci. 65:1531-1537.

(접수일자 : 2010. 1. 20 / 수정일자 : 2010.6.8/ 채텍일자 : 2010. 7. 22) 